\title{
リグノフェノールを用いた出土木材の保存処理（II） 劣化程度が異なる広葉樹材へのリグノフェノール の吸着特性と処理材の強度扣よび吸放湿特性一
}

\author{
片岡 太郎*1，栗本 康司*2，高妻 洋成*3
}

Conservation of archaeological waterlogged wood using lignophenol (II)

- Adsorption characteristics of lignophenol to hardwood degraded in various degrees, and surface hardness and adsorption/desorption of moisture in the treated hardwood -

Taro KATAOKA $^{* 1}$, Yasuji KuRIMOTo*2, Yohsei KohdzUMA*3

The amounts of lignophenol and polyethylene glycol 4000 (PEG4000) adsorbed by waterlogged wood in various degradation degrees were compared, and surface hardness of the samples treated with the lignophenol and PEG4000 were evaluated by a compression test. Average of maximum moisture content (MMC) was defined as degradation degree.

Samples were pieces of waterlogged wood of Tochinoki (Aesculus turbinata Blume) with an MMC of 284\%, and Doronoki (Populus maximowiczii A. Henry) with MMCs of 902\% and $1178 \%$.

The saturated adsorption amounts of the lignophenol per unit weight in MMC $284 \%$ samples were not so different from those of PEG4000, and in MMC 902\% and $1178 \%$ samples, the amounts were larger than those of PEG4000. In each MMC, wood hardness was consequently greater in the samples treated with lignophenol than that treated with PEG4000. Because of decrease in wood substance, however, the saturated adsorption amounts of lignophenol and PEG4000 per unit volume and hardness decreased in the samples with higher degradation degree. In each MMC, weight changes of the samples treated with lignophenol were small when the samples were exposed between $20 \% \mathrm{RH}$ and $90 \% \mathrm{RH}$ repeatedly. Therefore, the dimensional stability was improved by the increased hydrophobicity of cell walls. These results showed conservation using lignophenol was effective to waterlogged wood in the various degradation degrees.

* 1 秋田県立大学大学院生物資源科学研究科 - 日本学術振興会特別研究員 DC Graduate School of Bioresoure Sciences, Akita Prefectural University, JSPS Research Fellow, 11-1 Kaieisaka, Noshiro, Akita 016-0876, Japan

*2 秋田県立大学木材高度加工研究所 Institute of Wood Technology, Akita Prefectural University, 11-1 Kaieisaka, Noshiro, Akita 016-0876, Japan

*3 独立行政法人文化財研究所奈良文化財研究所 Independent Administrative Institution National Research Institute for Cultural Properties, Nara, 2-9-1, Nijo-cho, Nara City 630-8577 Japan 
Keywords : Waterlogged wood, lignophenol, polyethylene glycol, adsorption, surface hardness

最大含水率を劣化程度の指標として, 広葉樹出土木材へのリグノフェノールの吸着特性, 薬剂処理後の表面硬さと吸放湿特性をポリエチレングリコール（PEG4000）と比較検討した。 出土木材は最大含水率が $284 \%$ のチノキ, $902 \%$ と $1178 \%$ のドロノキを用いた。

単位重量当りのリグノフェノールの飽和吸着量は，284\%試料で PEG4000と大差なかった が，それよりも劣化程度が高い $902 \%$ と $1178 \%$ 試料では增大した。単位体積当りでは薬剤の違 いによらず，容積密度の低下による吸着に有効な表面積の減少が影響して，劣化程度が高い ものほど飽和吸着量が減少した。リグノフェノール処理した試験片の表面硬さは，いずれの 劣化程度においても PEG4000よりも高い值を示した。劣化程度が高くなれば処理によらず表 面硬さは低下したが, これは木材実質の減少を反映したものである。リグノフェノール処理 は，試験片を $20 \%$ RH と $90 \%$ RH 下に置いた場合の重量変化が小さく，寸法安定性に優れるこ とが明らかとなった。

キーワード：出土木材, リグノフェノール, ポリエチレングリコール, 吸着, 表面硬さ

\section{1.はじめに}

我が国における遺跡の考古学的調査では, 木簡, 建築構造材, 工具, 農具, 武器, 祭祀具など多種 多様な木製遺物がしばしば発見される。こうした 木製遺物は，古来より木材が幅広く使用されてき たことを筧わせるものであり，日本の歴史と文化 を理解するにあたり，高い学術的価值を有し，博 物館等に抢いて展示するなどの普及・啓発に供し つつ，普遍的に伝えていく必要がある。

出土木製遺物は通常, 出土木材 (Waterlogged Wood）と呼ばれている。日本における出土木材は， 湿潤な土壤から水浸しの状態で発見される場合が ほとんどである。出土木材は，長期間土中に埋没 している問に木材実質の一部が分解消失してお り,新たに形成された空隙には水が浸入している。 そのため, 新材に比べて容積密度および強度の低 下，最大含水率の增大が生じている1)。

このような状態にある出土木材は，乾燥によっ て著しい収縮・変形を生じるため, 博物館などに おいて展示・保管するには，必要な強度の付与と 乾燥状態への移行を図るための保存处理が行なわ れる。強度を付与するための方法としては，平均 分子量が3300のポリエチレングリコール (PEG 4000）などの可溶性の薬剤を木材中に含浸させる 方法が採られている。
しかし、このような従来法によって出土木材を 保存処理する場合，十分な強度の確保々形状の維 持のためには薬剤の含浸量を多くしなければなら ず，処理後の出土木材の重量が処理前のそれより も著しく増大する。このことが一要因となり，取 り扱いによっては保存処理後の出土木材が，応力 の集中する箇所で破損するという問題が起きてい る。また，展示・保管にともなう運搬を考慮した 場合, 保存処理後の出土木材は必要な强度を有し ながら軽量である方が望ましい。

本研究は,リグノフェノール2を用いて出土木 材の細胞壁を選択的に強化することで，木材本来 が持つ軽量でありながら強度が高いという特性を 活かした保存处理方法を開発することを目指して いる。ここで用いるリグノフェノールは木材成分 のリグニンから誘導される物質であり，リグノセ ルロース系材料に収着させることによって，木材 の特性を活かしつつ，その複合体に強度の向上お よび疎水性の付与ができる薬剂として広く研究さ れている3,4)。また，出土木材を保存処理する際 に用いる薬剤は，従来よりも優れた方法が将来開 発される場合を考えて，可逆的に使用できるもの が望ましいとされている。リグノフェノールはエ タノールや $t$-ブチルアルコール（TBA）などのア ルコール類に可溶であるため，そのような文化財 の保存・修復を行う際のそのような基本的な考え 


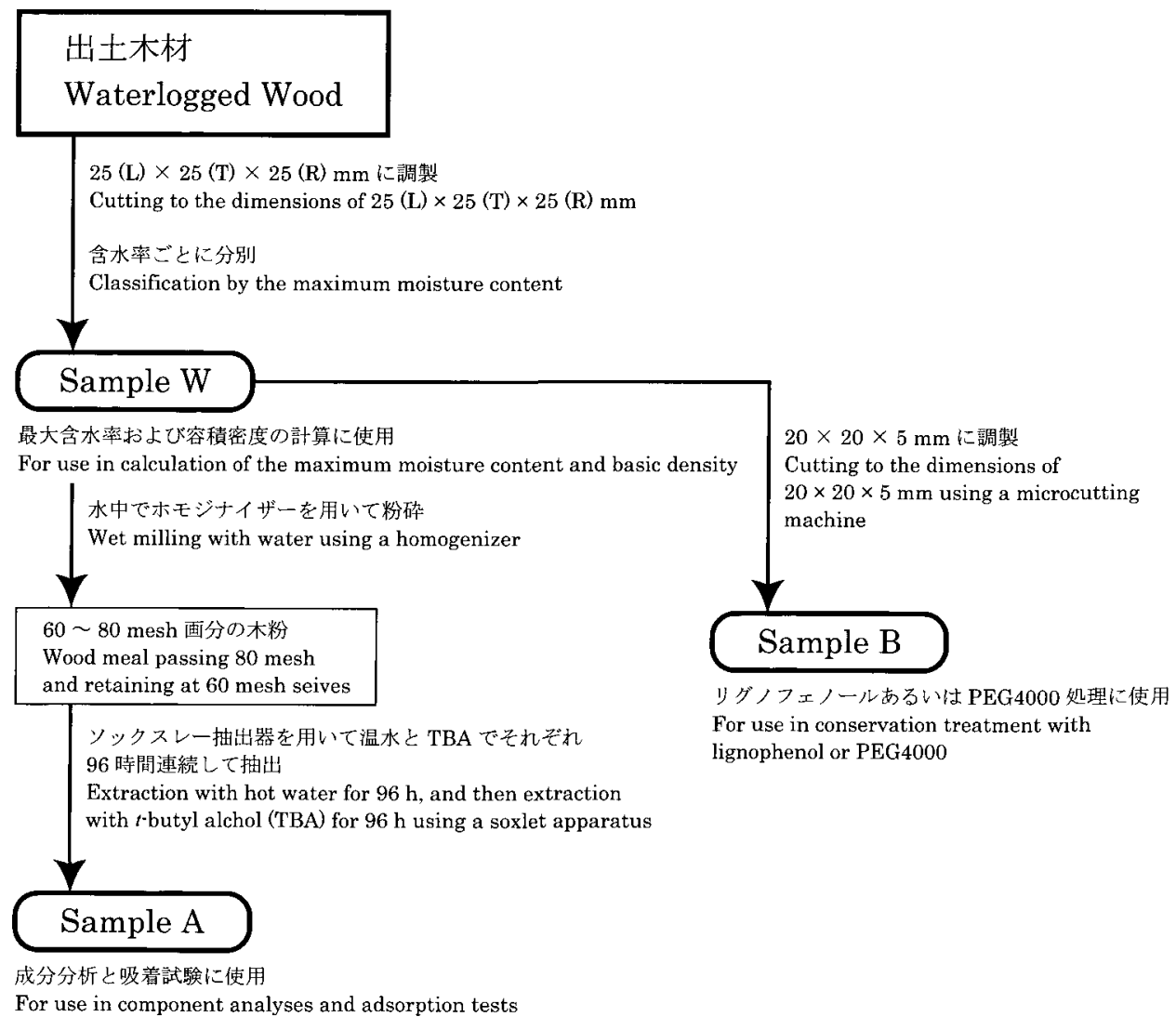

図 1 試料調製手順

Fig. 1 Preparation procedures of wood meals (Sample A) and wood specimens (Sample B).

方にも適している薬剤である。

既に, 我々は最大含水率が559\%の出土ムクノキ (Aphananthe aspera (Thunb.) Planch.) を用いた検 討で,リグノフェノールの細胞壁への吸着量を従 来用いられている PEG4000よりも多くすること ができること，ならびに処理後の試験片の強度が 大きく向上することを明らかにした5!。

通常, 発見される出土木材の樹種は様々である だけでなく，同一樹種であっても，劣化程度が異 なる場合が多い。今後リグノフェノールを用いた 保存処理方法の実用化を目指すためには，樹種や 木材の劣化程度がリグノフェノールの吸着特性や 処理材の強度特性へ及ぼす影響も検討する必要が ある。

出土木製遺物の保存科学分野では木材の劣化程

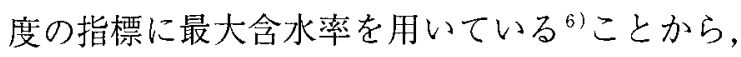
本報では，最大含水率が異なる広葉樹出土木材へ のリグノフェノールの吸着特性をPEG4000のそ れと比較検討するとともに，処理後の試験片の強
度特性および吸放湿特性を評価した。

\section{2. 実験}

\section{1 供試材}

出土木材は, 島根県大田市三瓶町「三瓶小豆原 埋没林」より出土したトチノキ (Aesculus turbinata Blume), 山形県山形市「梅野木前 1 遺跡」より出 土したドロノキ (Populus maximowiczii A. Henry) を用いた。

\section{2 木粉試料および板状試験片の調製}

木粉試料㧍よび板状試験片の調製手順を図 1 に 示す。供試材から，亀裂，虫食い穴，節やアテが ある部分を避けて25（緎維方向, L) ×25（接線方 向， T） $\times 25$ (放射方向， R） $\mathrm{mm}$ の試料（Sample W）を調製した。減圧下で飽水処理した後, 飽水時 の重量ならびに水中における重量を測定して最大 含水率㧍よび容積密度をそれぞれ計算した ${ }^{6)}$ 。そ の後, 最大含水率ごとに分別した Sample W をそ れぞれ水中でホモジナイザー（特殊機化工業株式 
会社製 T. K. HOMODISPER f model）を用いて粉 砕した。それらの60～80mesh 画分をソックスレー 抽出器により温水抒よび TBA で96時間ずつ連続 して抽出し，乾燥させないまま Sample A とした。 一方, Sample W から辺長が20mm の正方形で厚さ が $5 \mathrm{~mm}$ の木取りが異なる 3 種類の板状試験片を 切り出し，それらを Sample B 板目片，柾目片，木 口片とした。

\section{3 成分分析}

真空凍結乾燥したSample A を,ソックスレー 抽出器を用いてエ夕ノール・ベンゼン混合溶液 （1：2 容）で24時間抽出した後，減圧下でTBA 置換し，再度真空凍結乾燥して脱脂木粉とした。 脱脂木粉加ら JIS P 8012 ${ }^{7)}$, JIS P 8007 ${ }^{8)}$, JIS P $8008^{91}$ に基ういてホロセルロース， $\alpha$-セルロース， クラーソンリグニン招よび酸可溶性リグニン含有 率を求めた。

\section{4 リグノフェノールの調製5)}

60〜80mesh 画分のスギ材 (Cryptomeria japonica D. Don）をソックスレー抽出器を用いてエタノー ル・ベンゼン混合溶液（1：2容）で48時間抽出 した後，相分離系変換システム ${ }^{10)} に$ 従って調製し たリグノ-p-クレゾールの TBA 抽出画分をリグ ノフェノールとした。

\section{5 吸着能の測定}

吸着媒にはSample A 用いた。TBA系では減 圧下で再度 TBA を用いて飽和させた試料を実験 に供した。一方，水系での吸着実験では試料中の $\mathrm{TBA}$ を減压下で脱イオン水に置換した。吸着質に はリグノフェノールまたは PEG4000を用いた。溶 媒にはTBA または脱イオン水を用いた。吸着温度 を $55^{\circ} \mathrm{C}$ とし, 吸着量は, 前報 ${ }^{5)}$ と同様に, 吸着処理 前後の上澄液の濃度差から求め, 濃度測定は重量 法によった。なお，吸着時間は，前報5)で得られた 結果から 1 週間とした。

\section{6 板状試験片のリグノフェノール処理}

Sample B t TBA 系の場合では減圧下で TBA を飽和させ，水系での処理では減压下で脱イオン

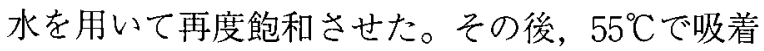
質濃度 $5 \%$ に調製したリグノフェノールまたは PEG4000溶液に 1 週間浸漬し, 真空凍結乾燥した。 乾燥後の重量（全乾重量）を測定した後，一ヶ月 間 $20^{\circ} \mathrm{C} ， 65 \% \mathrm{RH}$ の恒温恒湿室で調湿した。

\section{7 表面硬さ測定}

2.6 で処理した試験片を,圧縮ジグ（直径 $7 \mathrm{~mm}$ ） を取り付けた卓上型材料引張圧縮試験機（A＆D 社製 STA-1150）を用いて, 試験片の厚み方向をク ロスヘッドの負荷速度 $0.5 \mathrm{~mm} / \mathrm{min}$ でめり迟み量 が $1 \mathrm{~mm}$ になるまで変形させた。本実験は, JIS Z 2101 ${ }^{11}$ で規定される木材の硬さ試験とは異なる ため, 測定で得られた荷重一変位量曲線から, 変 位量 $0.2 \mathrm{~mm}$ になる時の荷重值を表面硬さ $\mathrm{H}(\mathrm{N})$ と定義した。以上の試験は，各処理条件で 5 個の 試験片を用いて, $20^{\circ} \mathrm{C}, 65 \% \mathrm{RH}$ の恒温恒湿室内で 行った。

\section{8 吸放湿繰り返し試験}

表面硬さ試験後の出土木材試験片（木口木取り のみ）を温度 $20^{\circ} \mathrm{C}$ の恒温室内にて, $20 \% \mathrm{RH}$ に調節 したデシケータ内に24時間置き，その後 $90 \% \mathrm{RH}$ に調節したデシケータ内に移して24時間置き，そ のつど試験片の重量を測定して含水率を求めた。 この操作を 5 回（総計216時間）繰り返して,20\% RH と $90 \%$ RH 下における試験片の含水率差 (24時 間）の平均值を変動值として吸放湿特性を評価し た。なお， $20 \%$ RH 環境は酷酸カリウム飽和水溶 液， $90 \%$ RH 環境は塧化カリウム飽和水溶液で調 整した。

\section{3. 結果と考察}

\section{1 供試出土木材の劣化状態}

\section{1 .1 最大含水率㧍よび容積密度}

表 1 に Sample W (図 1 参照) から求めた出土卜 チノキおよびドロノキの最大含水率の平均値 （MMC）拉よび容積密度の平均値（BD）をそれぞ れ示す。また，それらに加えて前報5で用いた出土 ムクノキの值も示す。

BD が低い試料ほど MMCが高くなっており， これは既往の報告 ${ }^{11}$ と同様の結果であった。容積 密度が低い試料ほど最大含水率が高くなるという 関係は, 出土木材の劣化では, 木材実質が消失し た部分は空隙となり，その新たに生じた空隙には 水が充填されていることを示すものである。

\section{1 .2 成分組成}

表 2 に Sample A（図 1 参照）から求めた出土卜 チノキおよびドロノキ，ムクノキのホロセルロー ス， $\alpha$-セルロース, クラーソンリグニン, 酸可溶 
表 1 供試出土木材の最大含水率と容積密度

Table. 1 Maximum moisture content and basic density of waterlogged wood.

\begin{tabular}{|c|c|c|c|}
\hline $\begin{array}{l}\text { 和名 } \\
\text { Japanese name }\end{array}$ & $\begin{array}{l}\text { 学名 } \\
\text { Scientific name }\end{array}$ & $\mathrm{MMC}^{* 1}(\%)$ & $\mathrm{BD}^{* 2}\left(\mathrm{~g} / \mathrm{cm}^{3}\right)$ \\
\hline $\begin{array}{l}\text { トチノキ } \\
\text { Tochinoki }\end{array}$ & Aesculus turbinata Blume & 284 & 0.28 \\
\hline $\begin{array}{l}\text { ムクノキ } \\
\text { Mukunoki }\end{array}$ & Aphananthe aspera (Thunb. ) Planch & 559 & 0.16 \\
\hline $\begin{array}{l}\text { ドロノキ } \\
\text { Doronoki }\end{array}$ & Populus maximowiczii A. Henry & 902 & 0.10 \\
\hline $\begin{array}{l}\text { ドロノキ } \\
\text { Doronoki }\end{array}$ & Populus maximowiczii A. Henry & 1178 & 0.08 \\
\hline
\end{tabular}

* 1 最大含水率 Maximum moisture content

* 2 容積密度 Basic density

表 2 供試出土木材の成分組成

Table. 2 Chemical constituents of waterlogged wood.

\begin{tabular}{|c|c|c|c|c|c|}
\hline $\begin{array}{l}\text { 和名 } \\
\text { Japanese name }\end{array}$ & $\operatorname{MMC}^{* 1}(\%)$ & $\begin{array}{l}\text { ホロセルロース } \\
\text { Holocellulose }(\%)\end{array}$ & $\begin{array}{l}\alpha-\text { セルロース } \\
\alpha \text {-Cellulose (\%) }\end{array}$ & $\begin{array}{l}\text { クラーソンリダニン } \\
\text { Klason lignin }(\%)\end{array}$ & $\begin{array}{l}\text { 酸可溶性リグニン } \\
\text { Acid-soluble lignin (\%) }\end{array}$ \\
\hline $\begin{array}{l}\text { トチノキ } \\
\text { Tochinoki }\end{array}$ & 284 & $61.6(174.9)^{* 2}$ & $39.9(113.3)$ & $33.2(94.3)$ & $1.5(4.3)$ \\
\hline $\begin{array}{l}\text { ムクノキ } \\
\text { Mukunoki }\end{array}$ & 559 & $29.3(46.9)$ & $12.2(19.5)$ & $66.6(106.6)$ & $1.7(2.7)$ \\
\hline $\begin{array}{l}\text { ドロノキ } \\
\text { Doronoki }\end{array}$ & 902 & $20.0(20.6)$ & $5.5(5.7)$ & $69.6(71.7)$ & $1.3(1.3)$ \\
\hline $\begin{array}{l}\text { ドロノキ } \\
\text { Doronoki }\end{array}$ & 1178 & $21.0(16.8)$ & $6.1(4.9)$ & $68.8(55.0)$ & $1.6(1.3)$ \\
\hline
\end{tabular}

* 1 最大含水率 Maximum moisture content.

*2 括弧外数值は単位重量当りの含有率, 括弧内は単位体積当りの含有率をそれぞれ表す。Values in parentheses show weight（mg）of each constituent in an unit volume $\left(\mathrm{cm}^{3}\right)$.

性リグニンの単位重量当たりの含有率をそれぞれ 示す。

ホロセルロースおよび $\alpha$ セルロースは，MMC が高い試料ほど低い值を示した。ただし，MMC 902\%と $1178 \%$ (ドロノキ)の試料ではホロセル ロースが約 $20 \% ， \alpha$-セルロースは約 $6 \%$ であり， それぞれ大差なかった。

クラーソンリグニンは, MMCが $284 \%$ の試料で $33.2 \%$ あったものが，559\%の試料では約 2 倍 (66.6\%) になった。しかしながら，ムクノキ，ド ロノキ (MMC902\%および1178\%) では，その MMC が著しく異なるにもかかわらず，いずれも 約70\%と同等であった。酸可溶性リグニンと MMCには，一定の傾向は認められなかった。

一般に, 出土木材の成分組成については, 劣化 の進行，すなわち最大含水率の增大とともに，多 糖類の含有率が著しく減少し, 相対的にリグニン 含有率が增大することが知られて扔り, 本研究に
おいても同様の結果が得られた。 次に，単位体積当りの重量を各成分の含有率を もとに計算した值を表 2 の括弧内に示す。

ホロセルロースは, MMCが284\%のトチノキで は $174.9 \mathrm{mg} / \mathrm{cm}^{3}$ であるのに対して，1178\%のドロ ノキでは1/10の $16.8 \mathrm{mg} / \mathrm{cm}^{3}$ にまで減少した。ク ラーソンリグニンは，MMCが284\%拈よび559\% の試料で約 $100 \mathrm{mg} / \mathrm{cm}^{3}$ であったが，1178\%の試料 では $55.0 \mathrm{~g} / \mathrm{cm}^{3}$ と約 $1 / 2 に$ 減少した。このように単 位体積当りの成分重量をみた場合, 出土木材の劣 化の進行にともなって，セルロースだけでなく， リグニンも分解消失することは高妻らの研究 ${ }^{1}$ と 同様の結果であった。

\section{2 出土木材の劣化状態が吸着特性に与える影響}

各実験系について, 吸着媒に Sample A（図 1 参 照）を用いて得られた吸着量から吸着等温線を作 成した。例として，MMCが $902 \% の$ 試料（ドロ） キ)について，吸着温度 $55^{\circ} \mathrm{C}, \mathrm{TBA}$ 系におけるり 


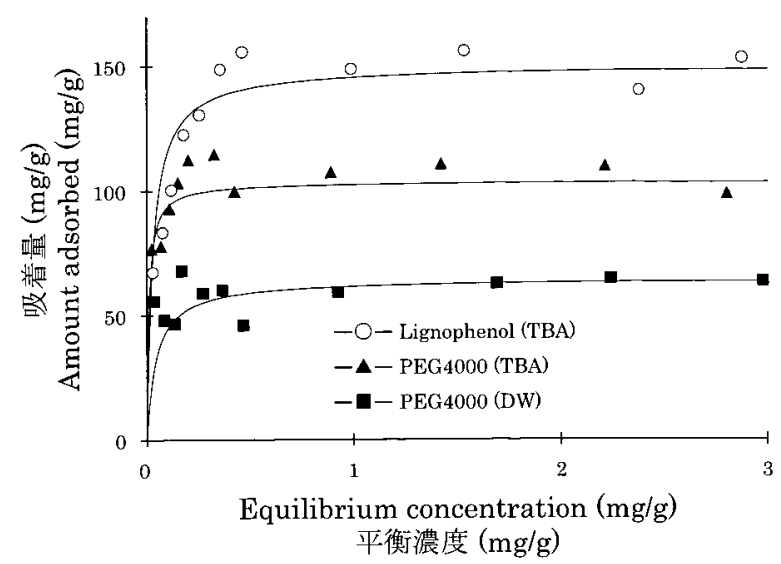

図 2 出土ドロノキ(MMC902\%)の TBA 系55 Cにお けるリグノフェノールおよび PEG4000，水系 $55^{\circ} \mathrm{C}$ における PEG4000の昅着等温線

Fig. 2 Adsorption isotherms of lignophenol and PEG4000 from their $t$-butyl alcohol (TBA) solutions and of PEG4000 deionized water (DW) solution on Sample A of Doronoki (MMC902\%) at $55^{\circ} \mathrm{C}$, respectively.

グノフェノールおよびPEG4000，水系における PEG4000の吸着等温線を図 2 に示す。

いずれの测定でも平衡濃度の増大とともに吸着 量は増加し, 平衡濃度 $1 \mathrm{mg} / \mathrm{g}$ 以上で吸着量が一 定となった。また，吸着等温線の形はすべて Langmuir 型であった。PEG4000の吸着量は，TBA 系か らの方が氷系よりも多く，TBA 系に拈いては，リ グノフェノールの吸着量が PEG4000よりも多か つた。

次に，飽和吸着量を求めるために，図 2 のデー タをもとに Langmuir plotを行った。Langmuir 式を 変形すると以下のような直線式(1)が得られる。

$$
\frac{\mathrm{c}}{\mathrm{u}}=\frac{1}{\mathrm{k} \times \mathrm{u}_{\mathrm{s}}}+\frac{\mathrm{c}}{\mathrm{u}_{\mathrm{s}}}
$$

ここに, $\mathrm{c}$ は平衡濃度 (\%), $\mathrm{u}$ は吸着量 $(\mathrm{mg} / \mathrm{g})$, $\mathrm{k}$ は吸着定数， $\mathrm{u}_{\mathrm{s}}$ は飽和吸着量 $(\mathrm{mg} / \mathrm{g})$ である。 $\mathrm{c}$ に対して $\mathrm{c} / \mathrm{u}$ をプロットしたものを図 3 に示す。 いずれの場合も良い直線性が得られ, Langmuir 式との良好な適合性を示していることが明らかで ある。また、ここには示していないが，MMCが $284 \%$ の試料（トチノキ）拈よび1178\%の試料（出 土ドロノキ）の全ての测定結果においても Langmuir plotを行ったところ良好な直線性が得られ た。

式(1)の直線の傾きから計算した全ての樹種につ

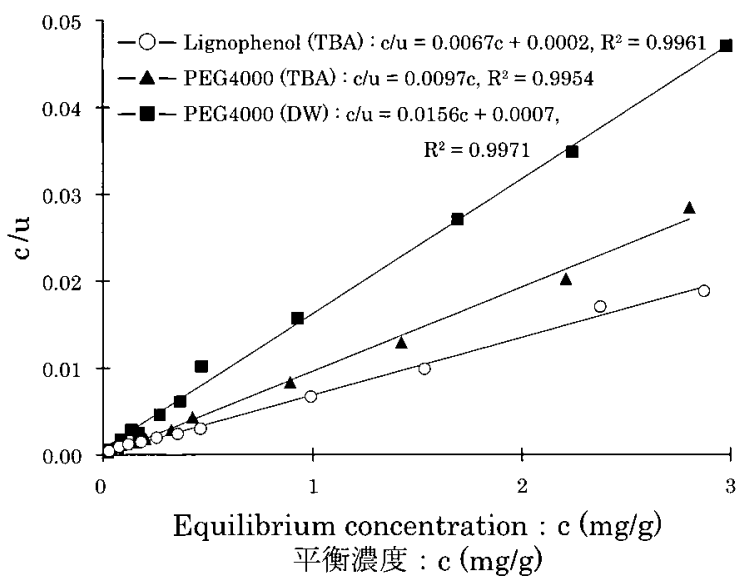

図 3 出土ドロノキ(MMC902\%)の TBA 系55ㄷ にお けるリグノフェノールおよびPEG4000，水系 $55^{\circ} \mathrm{C}$ における PEG4000の Langmuir plot

Fig. 3 Langmuir plots for adsorption of lignophenol and PEG4000 from their $t$-butyl alcohol (TBA) solutions and of PEG4000 deionized water (DW) solution on Sample $A$ of Doronoki (MMC902\%) at $55^{\circ} \mathrm{C}$, respectively.

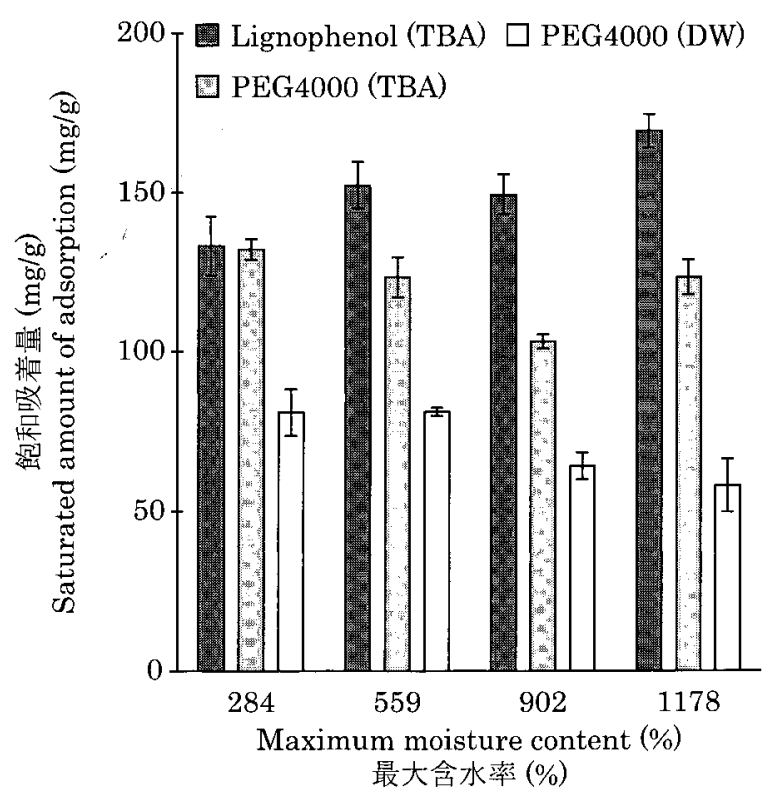

図 4 最大含水率、吸着条件ごとの単位重量あたりの リグノフェノールおよび PEG4000の飽和吸着 量

Fig. 4 Saturated amounts of adsorption of lignophenol and PEG4000 at different adsorption conditions.

いての単位重量当りの飽和吸着量を, 前報 ${ }^{5)}$ で示 したムクノキ(MMC559\%)の飽和吸着量と合わせ て図 4 に示す。

PEG4000の TBA 系に打ける飽和吸着量は, 水系 と比べて1.8～2.9倍多かった。溶媒を TBAにする 


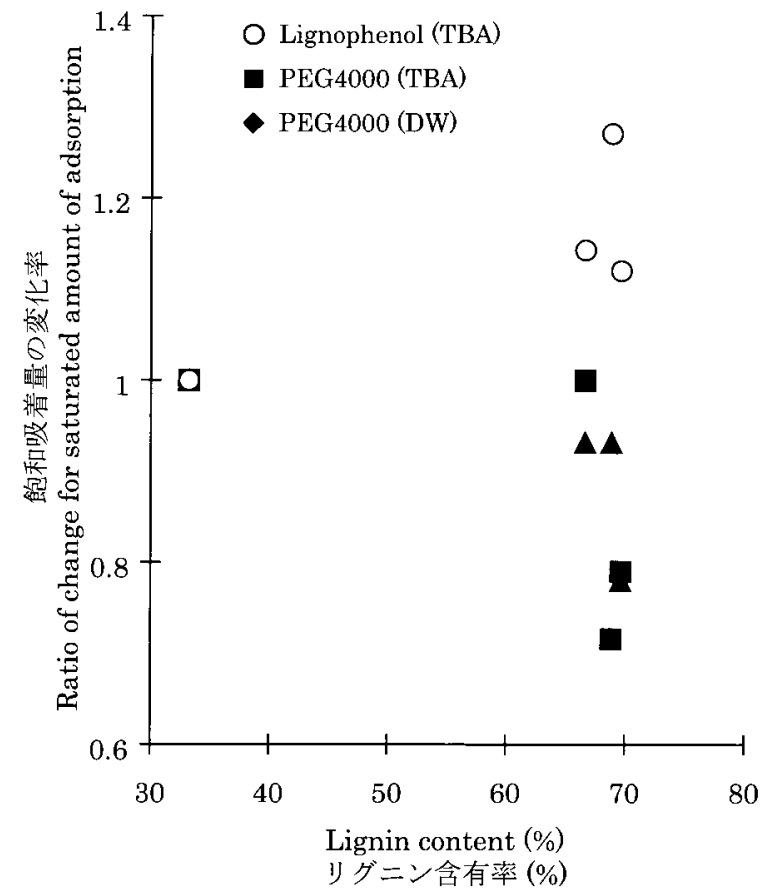

図 5 吸着条件ごとの試料リグニン含有率と飽和吸 着量の関係

Fig. 5 Relationship between saturated amount of lignophenol or PEG4000 adsorption and lignin content of Sample $A$ at different adsorption conditions.

ことでPEG4000の飽和吸着量が水系よりも大き く增加した要因は，次のように考えられる。水系 では，木材と親和性の高い水が細胞壁と強い相互 作用で拘束されているためこれが障壁となり， PEG 分子が細胞壁に吸着されなかったが，TBA 系では,水よりも親和性が低い TBAに置換したこ とによって, 吸着層において $\mathrm{PEG}$ 分子と細胞壁と の親和性が得られ，吸着可能な PEG 分子数が増加 した ${ }^{5 !}$ 。また, TBA は水よりも PEGに対して唄溶 媒となることから, PEG 分子のコイルの広がりが 小さくなり ${ }^{12)}$, 結果としてより密度の高い吸着層 が形成され，吸着量が増加したことも一因と考え られる。

リグノフェノールの飽和吸着量は, 劣化程度が 低い試料 (トチノキ)では, 約 $130 \mathrm{mg} / \mathrm{g}$ と PEG 4000 (TBA 系) と大差ないが, MMCがこれより高い試 料においては，いずれもリグノフェノールの方が $20 \mathrm{mg} / \mathrm{g}$ 以上多かった。リグノフェノールの飽和 吸着量が PEG4000 (TBA 系) よりもさらに増大し たことは,リグノフェノールはTBAに対して PEGよりも溶解性が低く, より TBA が貧溶媒と

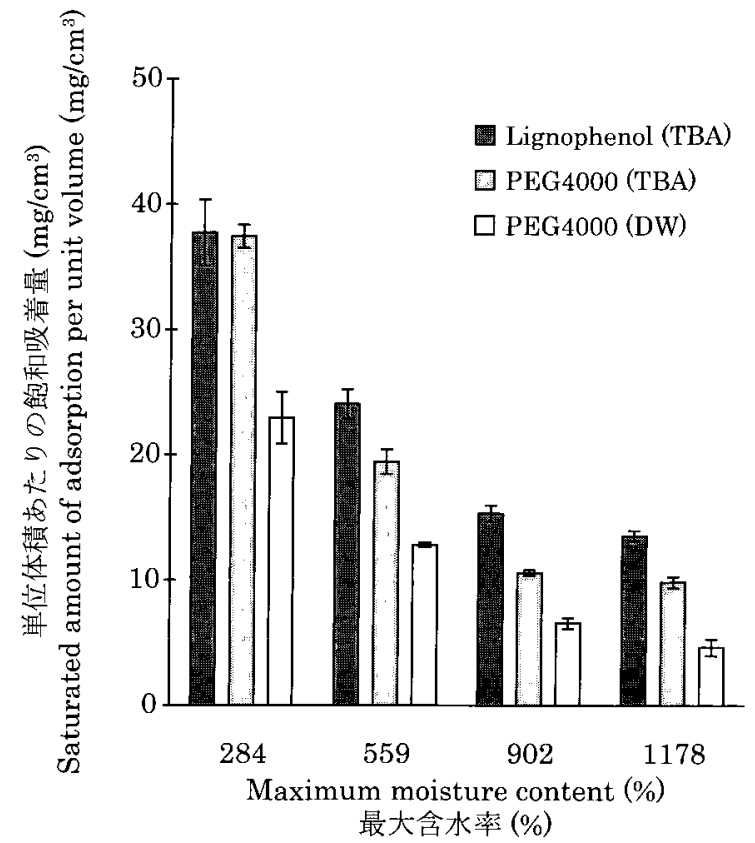

図 6 最大含水率, 吸着条件ごとの単位体積あたりの 飽和吸着量

Fig. 6 Saturated amounts of adsorption per unit volume at different adsorption conditions.

なることが一要因として考えられる。

3.1.2で述べたように, 出土木材は劣化が進行す れば単位重量当たりのセルロースの含有率が低く なり，相対的にリグニンの含有率が高くなる。そ こで, 単位重量当たりのリグニン含有率を横軸と して，MMCが $284 \%$ の試料（トチノキ）の飽和吸 着量を 1 とした場合のリグノフェノールと $\mathrm{PEG}$ 4000 (TBA 系拉よび水系) の飽和吸着量の変化率 をプロットして, 出土木材のリグニン含有率がこ れらの飽和吸着量へ及ぼす影響をみた（図 5)。図 から明らかなように, リグニン含有率が高い試料 ほど PEG4000の飽和吸着量は小さかった。一方 で,リグノフェノールのそれは増大し，リグニン 含有率が $68.8 \%$ の試料（ドロノキ）は， $33.2 \%$ の 試料（トチノキ）と比べて1.3倍大きくなった。こ れは，MMCが高い出土木材ほどリグニン含有率 が高いことから，疎水性であるリグノフェノール と出土木材との親和性が高いことによるものと思 われる。

次に, 図 4 のデー夕を元にして計算した単位体 積当りの飽和吸着量を図 6 に示す。全乾木粉重量 当りの飽和吸着量をみた場合と同様に, リグノフ エノールの飽和吸着量が全ての実験系において最 


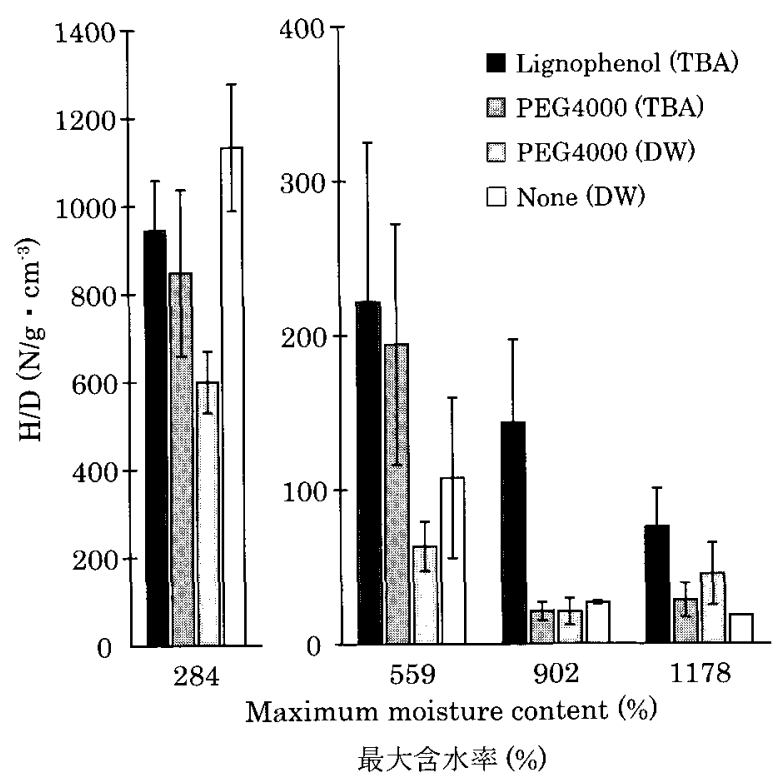

図 7 リグノフェノールあるいは PEG4000処理した 板目片の H/D 值

Fig. 7 Hardness/Density (H/D) on tangential surface of test specimens after conservation treatment with lignophenol or PEG4000.

も多いことがわかる。PEG4000をみた場合には, 溶 媒が TBAの場合の方が水よりも飽和吸着量は多 い。一方, MMC が高くなるほど, 薬剂や溶媒, 吸 着温度のいずれの条件においても飽和吸着量の絶 対量が減少することが認められた。これは, 劣化 の進行にともなう容積密度の低下，すなわち単位 体積当りの木材実質の減少が, 結果として, 吸着 に有效な表面積の減少をもたらしたことによるも のと考えられる。

\section{3 出土木材の劣化状態が表面硬さに与える影響}

リグノフェノールあるいは PEG4000処理後の

Sample B (図 1 参照) 用いて表面硬さ試験から求 めた表面硬さ $\mathrm{H}$ を得た。強度特性の評価には, 試 験片相互の密度の違いを考慮して, 表面硬さ $\mathrm{H}$ を処理後の試験片のみかけ密度で除した比表面硬 さ（H/D 值）を用いた。また， MMCが284\%のト チノキ，902\%拉よび1178\%のドロノキの H/D 值 とともに, 前報5)で得られたムクノキ( $\mathrm{MMC}$ 559\%）の H/D 值を合わせて木取りごとに検討を 行った。

図 7 に, 板目面に打计る H/D 值を MMC と処理 条件ごとに示す。MMCが284\%の試験片を除い て, 薬戍処理した試験片の H/D 值が無処理 (None (DW)）のそれよりも高い傾向にあった。薬棛処

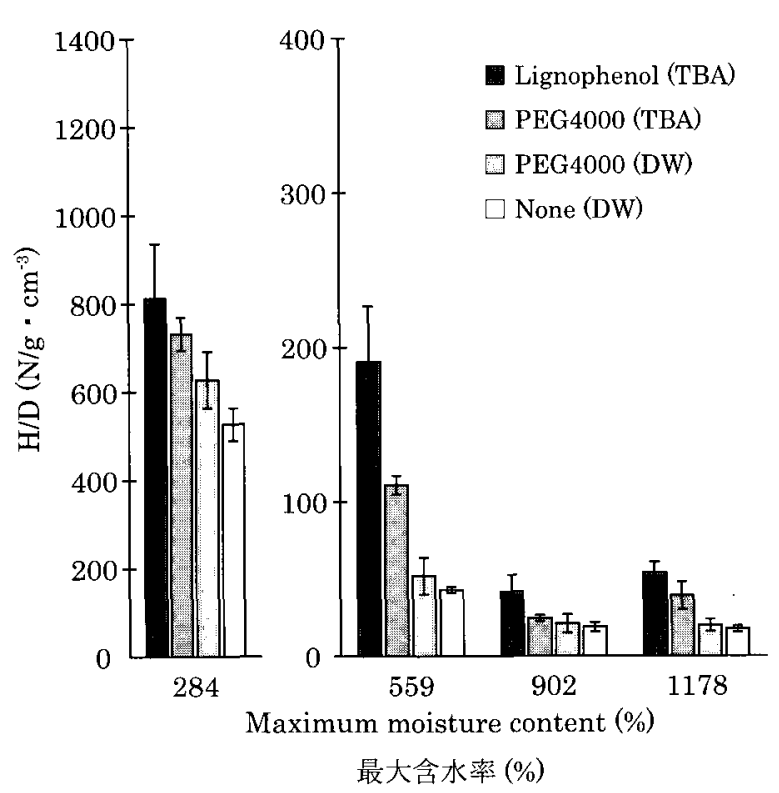

図8リグノフェノールあるいはPEG4000処理した 柾目片の H/D 值

Fig. 8 Hardness/Density (H/D) on radial surface of test specimens after conservation treatment with lignophenol or PEG4000.

理した試験片を見た場合，いずれの MMCにおい ても,リグノフェノール処理した試験片の H/D 值が PEG4000処理（TBA 系㧍よび水系）したもの よりも高い值が得られ，とりわけ，MMCが $902 \%$ の試料（ドロノキ）では, リグノフェノール処理 した試験片の H/D 值が PEG4000処理（TBA 系扔 よび水系）したものよりも 6 倍以上高い值を示し た。

図 8 に, 柾目面に扔ける $\mathrm{H} / \mathrm{D}$ 值を $\mathrm{MMC}$ と処理 条件ごとに示す。いずれの MMCにおいても薬剤 処理した試験片の H/D 值が, 無処理のそれよりも 高い值を示した。薬剤処理した試験片間の比較で は, 板目面と同様に, リグノフェノール処理した 試験片の H/D 值が, PEG4000処理（TBA 系㧍よび 水系）したものよりも高い值を示し，リグノフェ ノールの強度向上効果が大きく現れた。

図 9 に, 木口面における $\mathrm{H} / \mathrm{D}$ 值と MMC を処理 条件ごとに示す。MMCが $284 \%$ の試料では PEG (TBA 系) 処理, 902\%ではりグノフェノール処理 した試験片が最も高いH/D值を示した。MMC が最も高い試料（1178\%）においては無処理の試 験片が最も高い值を示したが，それよりも低い試 料 $(284 ， 559 ， 1178 \%)$ では, 薬剤処理した試験 片が無処理と比べて高い H/D 值を示した。このよ 


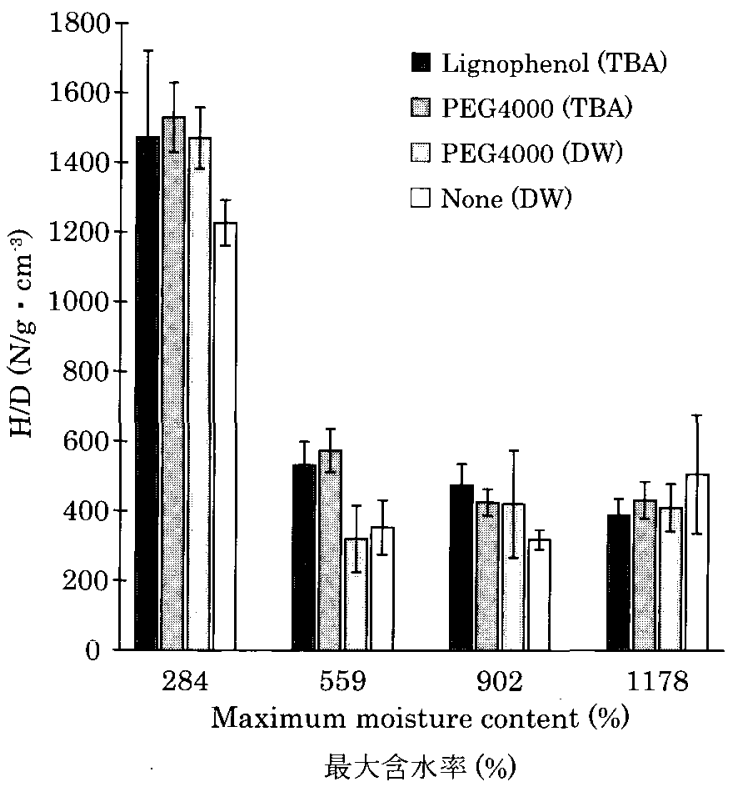

図 9 リグノフェノールあるいはPEG4000処理した 木口片の H/D 値

Fig. 9 Hardness/Density (H/D) on transverse surface of test specimens after conservation treatment with lignophenol or PEG4000.

うに，㕲面に扔いては，試料の MMC，薬剂処理 の有無や薬剤の種類と $\mathrm{H} / \mathrm{D}$ 值との間に, 明確な関 係は認められなかった。

以上を総じて，板目面，柾目面においては，薬 剤処理の効果が現れ，とりわけ，リグノフェノー ル処理した試験片では，PEG4000（TBA 系）ょり も高い H/D 值が得られた。

また，全ての木取りで，いずれの処理条件にお いても，MMCが高くなれば $\mathrm{H} / \mathrm{D}$ 值が低下した。 これは，劣化程度が高くなれば，単位体積当りの 木材実質が減少して, 強度が低くなることを反映 したものと考えられる。

以上から，出土木材の細胞壁を重点的に強化し て多孔質となるような保存処理を考える上で，リ グノフェノールを薬剤として用いることは，PEG 4000を用いることよりも有効であると考えられ る。しかしながら，木材実質の減少によって吸着 量の絶対量が減少することから，さらに強度を向 上させるためには，リグノフェノールの含浸量を 増やすなどして, 単位体積当りの吸着量を多くす る方法を考える必要がある。

\section{4 出土木材の劣化状態が吸放湿特性に与える} 影響

図10に, 表面硬导試験後の試験片（木口木取り

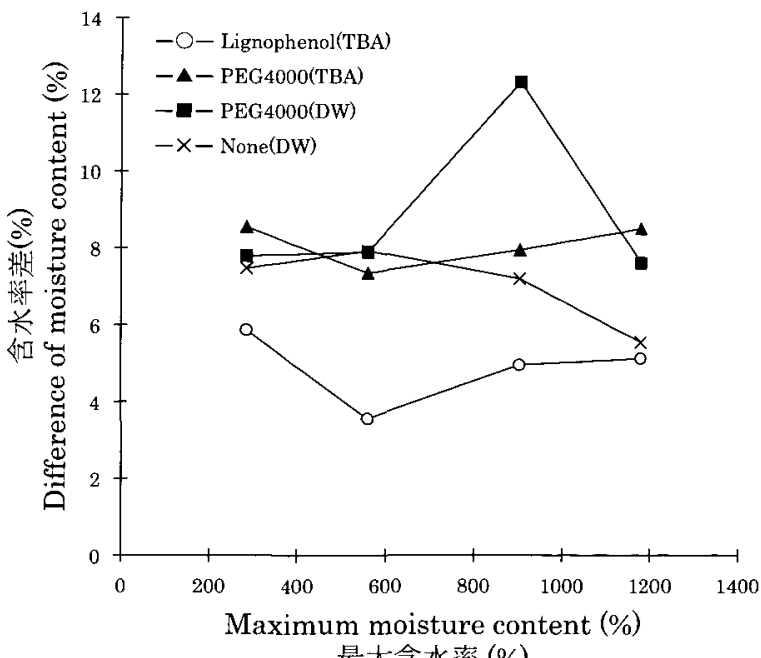

図10 20\%RH と90\%RH 下における試験片の含水率 差

Fig. 10 Differences of moisture content under changing relative humidity between $20 \%$ and $90 \%$ in different conservation conditions.

のみ）の $20 \% \mathrm{RH} と 90 \% \mathrm{RH}$ 下における含水率差 (24時間) の変動值を前報5)で得られたムクノキ (MMC559\%) のそれと合わせて，MMC と処理条 件ごとに示す。

無処理の試験片 (None (DW)) の変動値は, MMC が高くなるにつれて若干の減少を示した。 水系に招いて PEG4000で処理した試験片は無処 理と比較すると，MMC が $284 \%$ の試料では差はな いが, $902 \%$ で $5,1178 \%$ で $\%$ 高い変動值を示 した。また，TBA系において PEG4000で処理した 試験片では, $1178 \%$ で $3 \%$ 高い変動值を示した。 一方, リグノフェノール処理した試験片の変動值 は，いずれの MMCの試料に拉いても 4 〜 $6 \%$ で あり，無処理やPEG 処理したそれよりも低い值を 示した。

以上から, MMCが異なっても, 出土木材をリグ ノフェノールで処理すれば疎水性が得られ，吸放 湿に伴う変形・収縮を抑制することができるもの と考えられる。

\section{4. まとめ}

最大含水率 $(\mathrm{MMC})$ を劣化程度の指標にして, MMC が異なる広葉樹出土木材へのリグノフェ ノールの吸着特性, 薬剂処理後の試験片の強度お よび吸放湿特性を評価した。 
全乾木粉重量当りのリグノフェノールの飽和吸 着量は, MMCが $284 \%$ と劣化程度が低い試料（下 チノキ)で PEG4000 (TBA 系) と大差なかったが， それよりも劣化程度が高い $902 \%$ および1178\%の ドロノキ試料ではPEG4000よりも多い值を示し た。これは, MMCが高い出土木材ほどリグニン含 有率が高いことから，踈水性であるリグノフェ ノールと出土木材との親和性が高いことによるも のと考えられた。一方, 出土木材単位体積当りの 飽和吸着量をみた場合, MMC が高いものほど, 薬 剂, 溶媒のいずれの条件においても, 飽和吸着量 が減少することが認められた。これは，劣化の進 行にともなう容積密度の低下，すなわち単位体積 当りの木材実質の減少が，吸着に有効な表面積の 減少に影響したことによるものと考えられた。

リグノフェノール処理した試験片では，劣化程 度にかかわらず板目面と柾目面において PEG 4000 (TBA 系扔よび水系) 処理試験片よりも高い $\mathrm{H} / \mathrm{D}$ 值が得られた。一方, MMCが高くなれば, 全 ての木取りと処理条件において $\mathrm{H} / \mathrm{D}$ 值が低下し たが，これは木材実質の減少が影響したことによ るものである。

MMCによらず，リグノフェノールで処理した 試験片が，PEG4000で処理したときよりも水蒸気 の吸放湿が少なかった。

以上のように，リグノフェノールは劣化がより 進行した出土木材ほど多く吸着し, 劣化程度にか かわらず表面硬さの向上に有効であった。しかし ながら，木材実質の減少による強度低下を補うた めには，さらに強度を向上させる必要があり，リ グノフェノールの含浸量を増やすなどして，単位 体積当りの吸着量を多くする方法を考える必要が ある。

今後, リグノフェノールを用いた保存処理方法 の実用化に向けた研究を行う上で針葉樹出土木材 への適用を検討するとともに，どの程度の含浸量 ならば展示・保管・運搬に必要な実用強度を確保 できるのかを中心に，単位体積当りのリグノフェ ノール量を多くするための検討を行う予定であ る。

\section{謝 辞}

本研究を遂行するに当り, 出土ドロノキを提供
していただきました福島県文化振興事業団小林啓 氏に心より深く感謝申し上げます。

\section{引用文献}

1) 高妻洋成, 湊和也,片山幸士：出土木材の種々 の性質間の関係，木材学会誌，42（7)，681-687 (1996).

2) 船岡正光, 阿部薫: 濃硫酸ークレゾール媒体 による木材成分の迅速分離，木材学会誌，35 (11)，1058-1062（1989).

3）齋藤猛：リグニン誘導体を利用した環境調和 型材料の開発 (I ) -リグニン誘導体と木粉の 熱圧成形一, 三重県科学技術振興センター工業 研究部研究報告, 26, 92-94 (2002).

4) 田中雅夫, 松井未来生：リグニン誘導体の生 分解性プラスチック複合材料への応用, 三重県 科学技術振興センター工業研究部研究報告,

28, 88-90 (2003).

5 ) 片岡太郎, 栗本康司, 高妻洋成: リグノフェ ノールを用いた出土木材の保存処理（I）ーリ グノフェノールの出土木材への吸着と強度拉よ び吸着特性一, 考古学と自然科学, 52, 39-50 (2006).

6）沢田正昭：“遺物の保存と調査”，独立行政法 人文化財研究所奈良文化財研究所編, 2003, pp. 19-28.

7 ）(財)日本規格協会：“JIS ハンドブック 紙・パ ルプ”, 1994, pp. 140-141.

8 ）財日本規格協会：“JIS ハンドブック 紙・パ ルプ”, 1994, pp. 132-133.

9 ）(財)日本規格協会：“JIS ハンドブック 紙・パ ルプ”, 1994, pp. 134-135.

10）船岡正光：相分離反応系を応用するフェノー ル系リグニン素材の誘導とその機能, 熱硬化性 樹脂, 16 (3)，35-49（1995）.

11）(財)日本規格協会：“JIS ハンドブック 建築 II 試験・設備”, 2003, pp.379-380.

12）石丸優：膨潤木材へのポリエチレングリコー ルの吸着一 - 一溶媒効果, 木材学会誌, 27 (3), 163-169 (1981).

(2006.11.14受付) (2007. 2 .15受理) 